\title{
Screening of Soil Bacteria for Phytase Activity
}

\author{
Andreea DOBRE ${ }^{1,2}$, Iulian GROSU ${ }^{1}$, Nicoleta ANDREI ${ }^{2}$, Alina BUȚU ${ }^{2}$, Călina Petruța CORNEA ${ }^{1}$ \\ ${ }^{1}$ University of Agricultural Sciences and Veterinary Medicine of Bucharest, Bulevardul Marasti, nr. 59, \\ Cod: 011464, Bucuresti, Romania, \\ ${ }^{2}$ National Institute of Research and Development for Biological Sciences, Bucharest, Splaiul \\ Independentei nr. 296, cod 060031, Bucuresti, Romania \\ * corresponding author: dobre_mc_andreea@yahoo.com
}

Bulletin USAMV series Agriculture 72(1)/2015

Print ISSN 1843-5246; Electronic ISSN 1843-5386

DOI 10.15835/buasvmcn-agr: 11184

\begin{abstract}
The aim of the present papaer was to realize a screening for phytase producing bacteria isolated from soil where pig manure was stored. It was used PSM, PKA media and the molybdate-blue method in order to determine the presence of phytase- phosphate solubilizing- and proteaze- producing bacteria. About half of the bacterial isolates were phytase producers
\end{abstract}

Keywords: bacteria, manure, phytase.

\section{INTRODUCTION}

An important environmental problem is the insoluble phosphate from soil, being about $80 \%$ from the total content of soil phosphorus (Mukhametzyanova et al., 2012). The most common form of phosphorus is phytic acid and phytates. Phytates are chelating agents, causing the formation of low degradable compounds. In nature, their hydrolysis is carried out by microbial phytases, which may potentially be used for innovative microbial technologies. Phytase (myoinositol hexakisphosphate 3-phosphorilase) catalyses the sequential release of phosphate by the hydrolysis of phytic acid in a stepwise manner, releasing lour inositol phosphates and inorganic phosphate. They can be synthesized both by micro organisms (bacteria, fungi and yeast) including the rumen microbes in ruminants, and soil microbes, and plants like wheat, barley, rice, corn or rye (Paik, 2003).

\section{MATERIALS SND METHODS}

Bacteria were isolated from soil sample collected from two households. Preliminary identification of the isolated strains was carried out on the basis of morphological analysis using Gram staining, microscopic observations and culture characteristics. The screening method for phytase activity was performed by using PSM (Bae et al., 1999). The PKA medium was used for testing inorganic phosphate solubilisation ability (Kaur and Reddy, 2013). The detection of clear zone surrounding the bacterial colonies is the sign of phosphate solubilising activity or phytase biosynthesis. The determination of phytase activity was made by molybdate-blue method. The experiment was realized with three repetitions in order to obtain accurate results. The detection of clear zone surrounding the bacterial colonies is the sign of phosphate solubilising activity or phytase biosynthesis. The efficiency of hydrolysis was determined by the formula $\mathrm{Z}-\mathrm{C} / \mathrm{C}$, were $\mathrm{Z}=$ halo diameter and $\mathrm{C}=$ colony diameter.

\section{RESULTS AND DISCUSSIONS}

Most of the isolated bacterial strains are Gram-. From 55 isolates, 27 are able to synthesize phytases, from which 17 presented high enzymatic activities (according to halo dimension and enzymatic assay). Additionally, 38 bacterial isolates have proteolytic activity (detected on casein containing medium) and only one proved to solubilise the inorganic phosphate (Tab.1). 
Tab. 1. The results obtained after screening

\begin{tabular}{|c|c|c|c|c|c|c|c|}
\hline Bacteria & $\begin{array}{c}\text { Phytases } \\
\text { synthetization }\end{array}$ & $\begin{array}{c}\text { Phophate } \\
\text { solubilization } \\
\end{array}$ & $\begin{array}{c}\text { Proteolytic } \\
\text { activity }\end{array}$ & Bacteria & $\begin{array}{c}\text { Phytases } \\
\text { synthetization }\end{array}$ & $\begin{array}{c}\text { Phophate } \\
\text { solubilization } \\
\end{array}$ & $\begin{array}{c}\text { Proteolytic } \\
\text { activity }\end{array}$ \\
\hline 1 & - & - & - & 31 & - & - & - \\
\hline 2 & - & - & + & 32 & +++ & - & ++ \\
\hline 3 & - & - & - & 33 & - & - & + \\
\hline 4 & - & - & + & 34 & + & + & ++++ \\
\hline 5 & - & - & ++++ & 35 & ++++ & - & + \\
\hline 6 & - & - & + & 36 & + & - & + \\
\hline 7 & - & - & + & 37 & - & - & +++ \\
\hline 8 & - & - & +++ & 38 & - & - & ++++ \\
\hline 9 & + & - & ++++ & 39 & - & - & +++ \\
\hline 10 & +++ & - & + & 40 & - & - & ++++ \\
\hline 11 & ++++ & - & ++++ & 41 & - & - & + \\
\hline 12 & ++++ & - & ++++ & 42 & ++ & - & - \\
\hline 13 & ++++ & - & + & 43 & - & - & - \\
\hline 14 & +++ & - & + & 44 & - & - & +++++ \\
\hline 15 & + & - & + & 45 & + & - & +++ \\
\hline 16 & + & - & - & 46 & - & - & +++ \\
\hline 17 & + & - & ++++ & 47 & - & - & ++ \\
\hline 18 & +++ & - & ++ & 48 & - & - & +++ \\
\hline 19 & + & - & ++ & 49 & - & - & + \\
\hline 20 & + & - & +++ & 50 & ++++ & - & ++++ \\
\hline 21 & ++ & - & ++++ & 51 & - & - & - \\
\hline 22 & - & - & +++ & 52 & - & - & - \\
\hline 23 & +++ & - & +++ & 53 & - & - & - \\
\hline 24 & ++ & - & ++ & 54 & - & - & - \\
\hline 25 & ++++ & - & + & 55 & - & - & - \\
\hline 26 & ++++ & - & + & & & & \\
\hline 27 & +++ & - & ++ & & & & \\
\hline 28 & +++ & - & + & & & & \\
\hline 29 & - & - & +++ & & & & \\
\hline 30 & +++ & - & +++ & & & & \\
\hline
\end{tabular}

\section{CONCLUSIONS}

According to the screening test, about half of the bacterial isolates were phytase producers. The best producers may be used in further studies for the remediation of soil polluted with insoluble phosphorus compounds.

Acknowledgments. This paper was published under the frame of European Social Fund, Human Resources Development Operational Programme 2007-2013, project no. POSDRU/159/1.5/S/132765

\section{REFERENCES}

1. Bae HD, Yanke LJ, Cheng KJ, Selinger LB (1999). A novel staining method for detecting phytase activity. J Microbiol Methods 39(1):17- 22.

2. Kaur G, Reddy MS (2013). Phosphate solubilizing rhizobacteria from an organic farm and their influence on the growth and yield of maize (Zea mays L.), J. Gen. Appl. Microbiol. 59: 295-303.

3. Mukhametzyanova AD, Akhmetova AI,Sharipova MR (2012). Microorganisms as Phytase

4. Producers. Microb. 81(3):267-275

5. Paik I (2003). Application of Phytase, Microbial or Plant Origin, to Reduce Phosphorus Excretion in Poultry Production. Asian-Aust. J. Anim. Sci.16(1):124-135. 